\title{
Environmental Impact Assessment of Automatic Brick Manufacturing Project at Lebukhali Dumki
}

\section{A. Parvez, M. T. Islam*, M. Islam, M. F. Haque and M. R. Ahmed}

Department of Environmental Science, Patuakhali Science and Technology University, Dumki, Patuakhali-8602

*Corresponding author: tariqulens@pstu.ac.bd

\begin{abstract}
The study has been conducted at USA Agro and Auto Bricks Ltd. at Lebukhali, Dumki Upazila under Patuakhali district. The purpose of this study is to find out the potential environmental impact during the construction operation and maintenance phase of the project and suggest effective mitigation measures to reduce negative impacts. Data necessary for the study has been collected through both primary and secondary data sources by literature review, Household Questionnaire Survey, Focus Group Discussion, and Key Informant Interview of surrounding people. Environmental Impact is analyzed through the calculation of Environmental Impact Value and Leopold matrix. Environmental Impact Value (+2) shows that the impact of the brickfield is low positive. Leopold matrix shows the pre, during and post construction value as 2.28, 1.56 and 1.82 where pre-impact is moderate, during and post-impact is low. Our estimated result shows that the negative impact of the project is minimum.
\end{abstract}

Key words: Automatic brickfield, Environmental impact assessment, Environmental impact value, Impact matrix

\section{Introduction}

From the beginning of civilization bricks have been used as an important material for the building of houses and other infrastructure; influencing economic progress. Rapid population growth and urbanization have created an increasing demand for residential, commercial, industrial, public buildings and other infrastructure in Bangladesh (Rahim, 2011). For this increasing demand, bricks are the most productive construction materials for both urban and rural areas. Brick making sector influences the countryôs economic growth by contributing about one percent of the countryôs gross domestic product (GDP) and also generating employment for about one million people (BUET, 2007). Though the overall importance of brick making sector in the countryô development is so high, most of the brick kilns using energy insensitive highly polluting technologies. This outdated technology emits around 6 million tons of $\mathrm{CO}_{2}$ annually, making it one of the largest sources of greenhouse gas emissions in the country (UNDP, 2011). The impact of brickfield is increasing day by day in Bangladesh as there is lack of government monitoring and intervention.

An increasing amount of brickfield has contributing to environmental pollution, biodiversity damage, the fertility of agricultural land is going down and the neighboring people of brickfield areas facing different health hazard (IUSS, 2002). Incomplete combustion of fossil fuels in brick field emits a considerable amount of pollutants that cause the problem to the environment, human health, plants, and animalôs life. In Bangladesh, brickfields are burning two million tons of low-quality coal and two million tons of firewood every year along with types and natural gas (Ahmed and Hossain, 2008). The usage of huge amounts of coal in brick donates meaningfully to releases of carbon dioxide $\left(\mathrm{CO}_{2}\right)$, particulate matter containing black carbon, sulfur dioxide $\left(\mathrm{SO}_{2}\right)$, oxides of nitrogen $\left(\mathrm{NO}_{2}\right)$, and carbon monoxide $(\mathrm{CO})$, etc. (Chindaprasirt et al., 2008).

As brick kiln emits a huge amount of particulate matter and PM has the capacity to travel deeper into the respiratory system (DoE, 2007), people exposed to it face different health problems such as asthma, lung cancer, chronic bronchitis, respiratory ailments, premature mortality from respiratory diseases, adult mortality from cardiopulmonary diseases and all-aged morbidity (Abbey et al., 1995; Pope et al., 2002; Ostro, 1994; Ostro, 2004; Jerin et al., 2016 and Guttikunda, 2009). An automatic brick manufacturing plant using Tunnel Kiln technology with coal gasification System is going to take place in West Angaria, Lebukhali, Dumki, Patuakhali to fulfill the increasing demand of brick in the southern region (ICPL, 2016). An Environmental Impact Assessment (EIA) has been conducted at automatic brick manufacturing project. EIA is the process of identifying the potential positive and negative impacts of any development project or action (Krishnamoorthy, 2005 and Kundu, 2011). Activities regarding the 
construction, operation, and maintenance of the project have some adverse impact which can affect the environment directly by ecological damages, pollution, affecting human health and indirectly by reducing agricultural land, changing land use patterns, destroying the growth and production of vegetation. The main purpose of this study is to find out the adverse environmental impact during the construction operation and maintenance phase of the project and suggest mitigation measures to the negative impacts.

\section{Materials and Methods}

\section{Study area}

The proposed project located at the southern coast of Lebukhali union in Dumki upazila under Patuakhali district of Bangladesh (Figure 1). Its geographical coordinates are $22^{\circ} 27^{\prime} 0^{\prime \prime}$ North latitude and $90^{\circ} 20^{\prime} 0$ " East longitude. The location is easy communicated both in road and river ways. It is bounded by Bakerganj upazila on the north, Patuakhali Sadar and Bauphal upazilas on the south, Bauphal Upazila on the east, Mirzaganj upazila on the west. Lebukhali is situated beside Paira River (BBS, 2015).

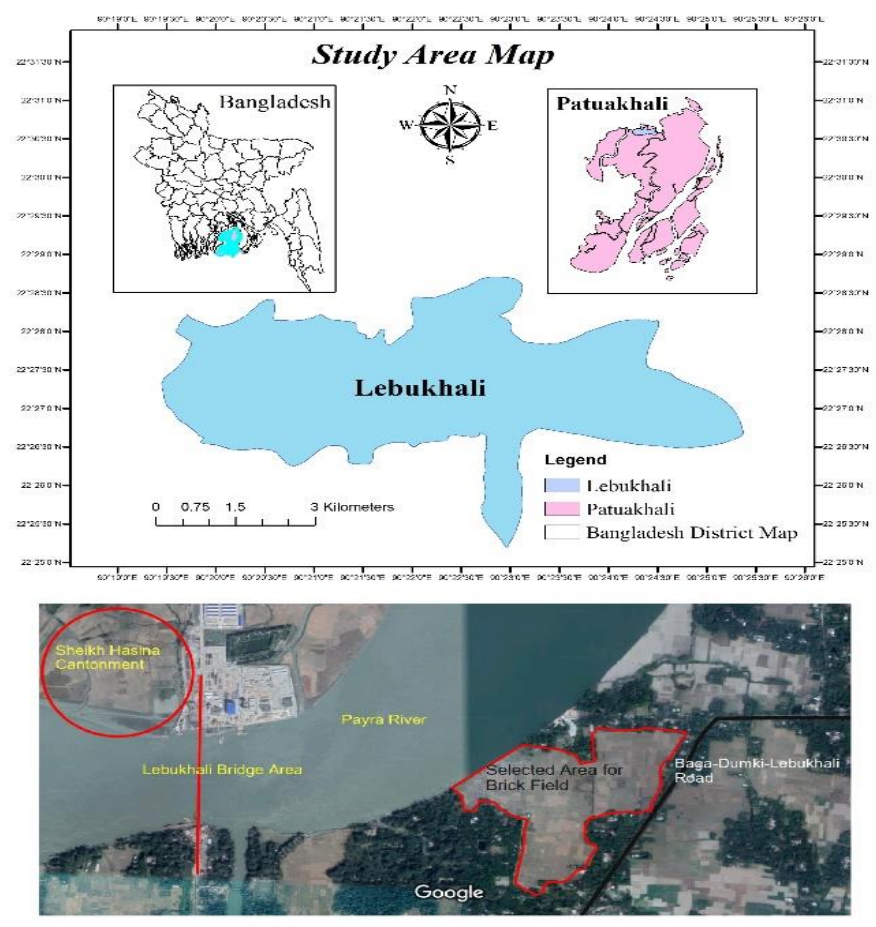

Fig. 1. Map of the study area

\section{Data collection}

This study was conducted based on available primary and secondary data. The primary data was collected through a Household Questionnaire Survey, Focus Group Discussion and Key Informant Interview. A total 50 questionnaire survey, 2 FGD, 10 KII were conducted for primary data. For questionnaire survey total 50 people were selected randomly in the study area. The household questionnaire survey was formulated with both open-ended and close-ended questions to attain more in-depth information from respondents. Local knowledgeable persons including community representatives, traders, teachers, and political leaders were interviewed individually to know their perception about the project. Secondary data and information for this study were collected from relevant books, daily national newspapers, journals, and websites.

\section{Data processing and analysis}

Collected data from different sources were analyzed by the help of Microsoft Office Excel sheet and SPSS software. For impact assessment, there used both Environmental Impact Value (EIV) and Leopold Matrix. The environmental impact value is calculated by the equation (Wilson, 1998; Saha, 2007):

$$
=
$$

Where,

EIV = Environmental impact value $\mathrm{Vi}=$ Relative change of the environmental quality of parameters 
$\mathrm{Wi}=$ Relative importance or weight or parameter

$\mathrm{N}=$ Total number of environmental parameters Changes of environmental parameters are severe $(+5$ or $-5)$, higher $(+4$ or -4$)$, moderate $(+3$ or -3$)$, low $(+2$ or $2)$, very Low (+1 or -1$)$, no change $(0)$.

Leopold matrix is used to identify the potential impact of a project on the environment. For Leopold matrix impact factors have been evaluated separately for each environmental component relevant for the scope of this study, and scored on a scale from 0 to 5 for impact magnitude, according to the following scale: 0-No observable effect, 1-Low effect, 2-Tolerable effect, 3Medium high effect, 4-High effect, 5- Very high effect (devastation).

\section{Results and Discussion}

The construction of an automatic brick manufacturing project will have both positive and negative impacts on the environment. During the questionnaire survey there found people who had both positive and negative response to the construction of the brick kiln. The impacts of the projects on the environment are described here based on peopleôs perception and field observation.

\section{Negative Impacts}

\section{Pollution to the environment}

Among the respondents $60 \%$ respond that particulate matter, $\mathrm{CO}_{2}, \mathrm{SO}_{2}, \mathrm{CO}, \mathrm{CFC}$ and $\mathrm{O}_{3}$ from burning coal and brick making and handling process will be increased to the environment as why it creates pollution to environment basically to air. $30 \%$ respondent deserves soil quality loss due to firing and burning the brick. Soil color and fertility recurrently changing. About 10\% respondent deserved about water quality due to oil spillage from water transportation, warm water and solid waste dump to the nearby water body.

\section{Ecological impact}

Ecosystem services from a different component such as flora, fauna, fish species and trees will be hampered badly. Removal of floral (tree, herb, and shrub) species would affect some bird habitat where they control their life cycle. Some common native fish species life cycle would be hampered. From the beginning of the project, $45 \%$ native bird species migrate due to the movement of human and machinery there. Almost $90 \%$ of native fish species migrate from the fallow land.

\section{Effects on agriculture}

There will be a loss of some agricultural production in the adjacent area to the brick kiln. Most of the respondents about $47 \%$ said that the construction of the brick kiln will not hamper their agricultural production at the same time $35 \%$ respondents think that there would be some negative impacts on their agricultural production rest of $17 \%$ respondent do not have any idea on the impacts. People who said that agricultural production will be affected by that project their land were very adjacent to the kiln.

\section{Health and safety}

Health and safety status of the surrounding people will be adversely hampered. About $55 \%$ of children and $75 \%$ older people are going to affect due to smoke and dust of the plant. As child labor engages this brick making process, $80 \%$ of them are not caring well. Younger people who are connected to burning brick are about $90 \%$ risky to burn diseases. Smoke from coal burning is encouraging $85 \%$ of diseases of their lung problem.

\section{Loss of land}

For the construction of the project, about 8 acres of land will be needed where included agricultural land, forest land, flood plain, and wetland. Majority of land is currently used for agricultural purpose. Majority of respondent about $63 \%$ said that they will lose their agricultural land, $25 \%$ will lose their fish culture land, $7 \%$ land is using for forest and rest of 5\% is grazing land. As there seen a huge amount of agricultural land the total crop production of this area will be dramatically decreased.

\section{Positive Impacts \\ Economic development}

This project tends to have a positive impact on industrialization and economic development of the surrounding area. Among the respondent, 95\% respond about increased of their economic condition as working, small business and renting of the house. Only $5 \%$ population deserves negative impacts that have lost their agricultural land. As it is an industry so production may influence the economic status of the respective area. Approximately up to 150 labors will engage with it and it will increase up to 250 with their family size.

\section{Employment generation}

For operation and maintenance of the project, some experienced people will need which will increase the employment opportunity. Newly transportation will move to this area where $95 \%$ truck that at least four people will get work along with one truck system and $5 \%$ others can chance of two-person per vehicles. Approximately 250 people will get employment at this project site.

\section{Estimation of environmental impact value (EIV)}

The Environmental impact value is estimated based on physicochemical, ecological, socio-cultural and human interest components. These components are further 
divided into different parameters for assessing the impact of thr project on these components during different stages of the projects. By using the equation no (i) Environmental Impact Value of the brick kiln project is estimated in Table 1. Estimated result of EIV showed that the project activities have both negative impacts on physicochemical (-121) and ecological (106) components and positive impacts on sociocultural $(+18)$ and human interest $(+207)$ components of the environment. We estimated the overall environmental impact value of the project is +2 (two). The estimated result means that the project has low positive on the environmental components so the project should be implemented. Though the projects have negative impacts on some environmental components these impacts can be mitigated by taking some mitigation and precautionary measures. After a successful implementation of the project, southern coastal people will get more benefit.

Table 1. Environmental impact value (EIV) estimation

\begin{tabular}{|c|c|c|c|c|}
\hline $\begin{array}{c}\text { Environmental } \\
\text { parameters }\end{array}$ & $\begin{array}{c}\text { Relative importance } \\
\text { value }\end{array}$ & $\begin{array}{c}\text { Degree of } \\
\text { impact }\end{array}$ & $\begin{array}{c}\text { Relative } \\
\text { impact }\end{array}$ & $\begin{array}{c}\text { Individual } \\
\text { EIV }\end{array}$ \\
\hline \multicolumn{4}{|c|}{ Physicochemical components } & \multirow{8}{*}{-121} \\
\hline Waste generation & 12 & -2 & -24 & \\
\hline Water quality & 8 & -1 & -8 & \\
\hline Soil erosion & 10 & -1 & -10 & \\
\hline Flooding & 4 & -1 & -4 & \\
\hline Air quality & 15 & -3 & -45 & \\
\hline Particulate matter & 12 & -2 & -24 & \\
\hline Sound pollution & 6 & -1 & -6 & \\
\hline \multicolumn{4}{|c|}{ Ecological components } & \multirow{8}{*}{-106} \\
\hline Fisheries & 12 & -2 & -24 & \\
\hline Vegetation cover & 20 & -3 & -60 & \\
\hline Forest & 10 & -1 & -10 & \\
\hline Plantation & 12 & +2 & +24 & \\
\hline Wildlife species & 5 & -1 & -5 & \\
\hline Wetland habitat & 7 & -1 & -7 & \\
\hline Ecosystem & 12 & -2 & -24 & \\
\hline \multicolumn{4}{|c|}{ Socio-cultural components } & \multirow{8}{*}{+18} \\
\hline Health problem & 10 & -2 & -20 & \\
\hline Cutting \& burning of trees & 15 & -2 & -30 & \\
\hline Socio-economic conditions & 22 & +3 & +66 & \\
\hline Current use of land & 6 & -3 & -18 & \\
\hline Social well-being & 14 & +3 & +42 & \\
\hline Excavations & 4 & -2 & -8 & \\
\hline Drainage capacity & 7 & -2 & -14 & \\
\hline \multicolumn{4}{|c|}{ Human Interest components } & \multirow{8}{*}{+207} \\
\hline Land use change & 8 & -1 & -8 & \\
\hline Employment & 29 & +4 & +116 & \\
\hline Loss of land & 15 & -3 & -45 & \\
\hline Migration & 2 & -1 & -2 & \\
\hline Economic development & 20 & +4 & +80 & \\
\hline Availability of bricks & 12 & +3 & +36 & \\
\hline Infrastructure development & 15 & +2 & +30 & \\
\hline \multicolumn{4}{|c|}{ Total Environmental Impact Value (EIV) } & +2 \\
\hline
\end{tabular}

\section{Environmental impact estimation by Leopold matrix}

Leopold matrix shows the impact of the project activities on different environmental components is estimated at different stages of the project. The environmental impact of the project is estimated at its pre-construction stage (Table 2), the construction stage (Table 3) and the operational stage (Table 4). At the pre-construction stage (Table 2 ) the average estimated effect of cumulative impact factors on environmental components is 2.28 . So the overall impact of different

project activities on physical, biological and sociocultural components is Medium. At the construction stage (Table 3 ) the average estimated effect of cumulative impact factors on environmental components is 1.56. So, in the construction stage impact of different project activities on physical, 
biological and socio-cultural components is low. At operational \& maintenance stage (Table 4 ) the average estimated effect of cumulative impact factors on environmental components is 1.82 . So, in the operation and maintenance stage, the overall impact of different project activities on physical, biological and socioeconomic components is low. After analyzing the result of Leopold matrix it is clear that project activities have low to medium impacts on different environmental components.

Table 2. Pre-construction stage impact matrix

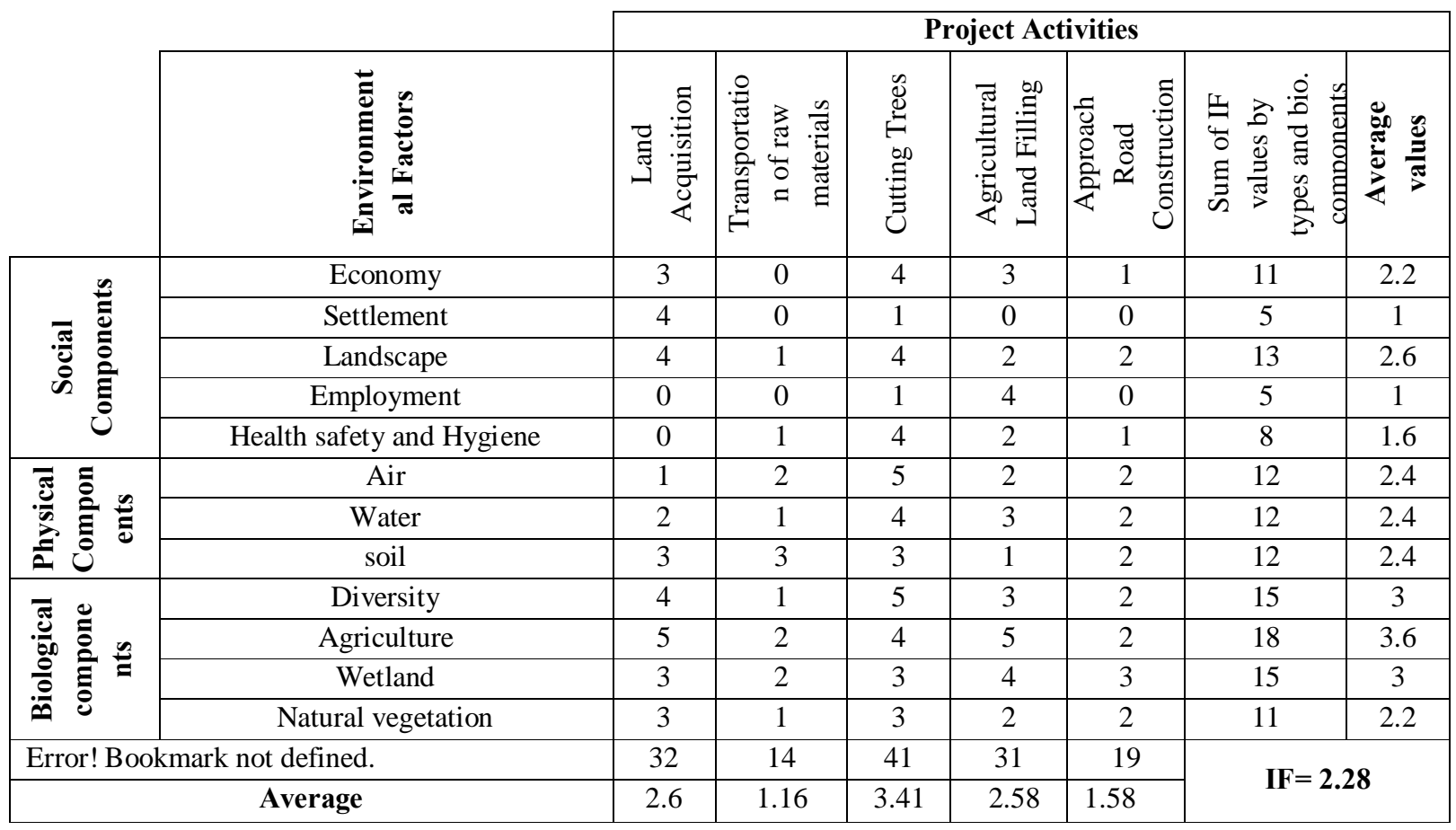

Table 3. Construction stage impact matrix

\begin{tabular}{|c|c|c|c|c|c|c|c|c|}
\hline & & \multicolumn{7}{|c|}{ Project Activities } \\
\hline & 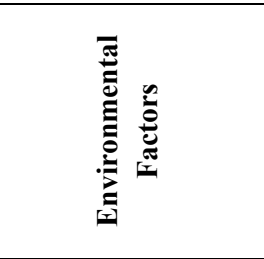 & 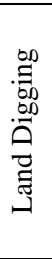 & 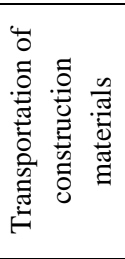 & 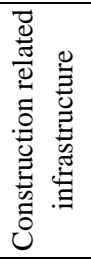 & 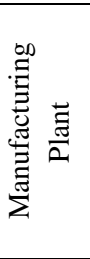 & 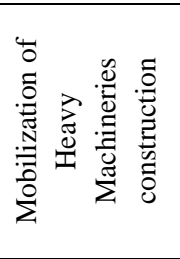 & 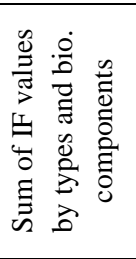 & 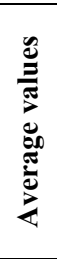 \\
\hline \multirow{5}{*}{ 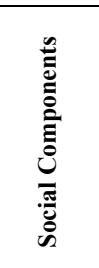 } & Economy & 0 & 0 & 0 & 1 & 0 & 1 & .2 \\
\hline & Settlement & 0 & 0 & 1 & 0 & 0 & 1 & .2 \\
\hline & Landscape & 0 & 2 & 2 & 0 & 2 & 6 & 1.2 \\
\hline & Employment & 0 & 0 & 3 & 2 & 1 & 6 & 1.2 \\
\hline & $\begin{array}{c}\text { Health safety and } \\
\text { Hygiene }\end{array}$ & 1 & 1 & 2 & 3 & 3 & 10 & 2 \\
\hline \multirow{4}{*}{ 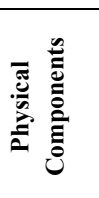 } & Air & 3 & 2 & 3 & 2 & 4 & 14 & 2.8 \\
\hline & Water & 2 & 2 & 3 & 2 & 3 & 12 & 2.4 \\
\hline & soil & 4 & 2 & 3 & 2 & 2 & 13 & 2.6 \\
\hline & Noise & 3 & 2 & 3 & 3 & 3 & 14 & 2.8 \\
\hline \multirow{4}{*}{ 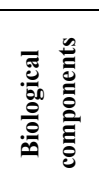 } & Diversity & 3 & 1 & 2 & 1 & 1 & 8 & 1.6 \\
\hline & Agriculture & 1 & 0 & 2 & 2 & 1 & 6 & 1.2 \\
\hline & Wetland & 0 & 0 & 2 & 1 & 2 & 5 & 1 \\
\hline & Natural vegetation & 0 & 1 & 2 & 2 & 1 & 6 & 1.2 \\
\hline
\end{tabular}




\begin{tabular}{|c|c|c|c|c|c|c|}
\hline $\begin{array}{l}\text { Cumulative values of IF } \\
\text { according to Social and } \\
\text { Environmental Factors }\end{array}$ & 17 & 13 & 28 & 21 & 23 & \multirow{2}{*}{ IF= $\mathbf{1 . 5 6}$} \\
\hline Average & 1.3 & 1 & 2.15 & 1.61 & 1.76 & \\
\hline
\end{tabular}

Table 4. Operation and maintenance stage impact matrix

\begin{tabular}{|c|c|c|c|c|c|c|c|c|}
\hline & \multirow[b]{2}{*}{ 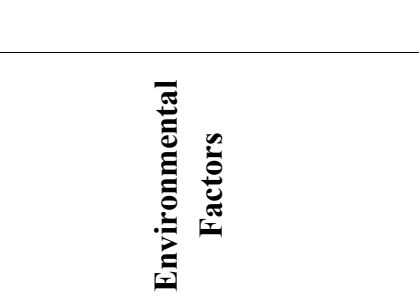 } & \multicolumn{7}{|c|}{ Project Activities } \\
\hline & & 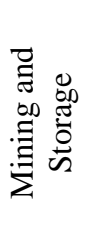 & 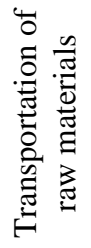 & 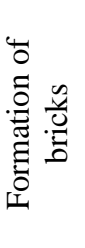 & 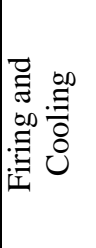 & 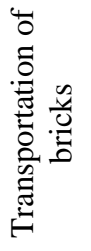 & 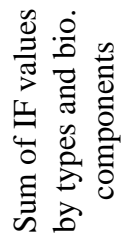 & 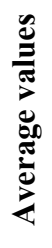 \\
\hline \multirow{5}{*}{ 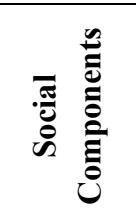 } & Economy & 0 & 0 & 3 & 2 & 3 & 8 & 1.6 \\
\hline & Settlement & 1 & 0 & 1 & 0 & 0 & 2 & .4 \\
\hline & Landscape & 3 & 1 & 0 & 0 & 1 & 5 & 1 \\
\hline & Employment & 2 & 1 & 4 & 1 & 3 & 11 & 2.2 \\
\hline & Health safety and Hygiene & 2 & 1 & 3 & 2 & 2 & 10 & 2 \\
\hline \multirow{4}{*}{ 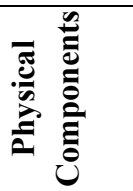 } & Air & 3 & 2 & 1 & 4 & 2 & 12 & 2.4 \\
\hline & Water & 3 & 1 & 3 & 2 & 3 & 12 & 2.4 \\
\hline & Noise & 2 & 2 & 1 & 4 & 2 & 11 & 2.2 \\
\hline & soil & 4 & 2 & 4 & 1 & 2 & 12 & 2.4 \\
\hline \multirow{4}{*}{ 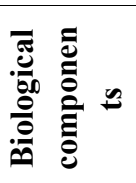 } & Diversity & 3 & 1 & 2 & 2 & 3 & 11 & 2.2 \\
\hline & Agriculture & 4 & 2 & 2 & 1 & 2 & 11 & 2.2 \\
\hline & Wetland & 2 & 1 & 2 & 1 & 1 & 7 & 1.4 \\
\hline & Natural vegetation & 2 & 1 & 0 & 1 & 2 & 6 & 1.2 \\
\hline \multicolumn{2}{|c|}{$\begin{array}{l}\text { Cumulative values of IF according to Social } \\
\text { and Environmental Factors }\end{array}$} & 31 & 15 & 26 & 21 & 26 & \multirow{2}{*}{\multicolumn{2}{|c|}{$\mathrm{IF}=1.82$}} \\
\hline \multicolumn{2}{|r|}{ Average } & 2.38 & 1.15 & 2 & 1.62 & 2 & & \\
\hline
\end{tabular}

\section{Mitigation measures}

As there is some negative impact of the project's activities on different environmental components. To overcome those negative impacts there some mitigation measures and suggestion are given in Table 5.

Table 5. Mitigation measures for possible negative impacts

\begin{tabular}{|l|l|l|}
\hline \multicolumn{1}{|c|}{ Aspect } & \multicolumn{1}{|c|}{ Issues } & Mitigation Measures/Suggestion \\
\hline \multirow{5}{*}{$\begin{array}{l}\text { Environment } \\
\text { management }\end{array}$} & Loss of acquisition & Relocation and Resettlement of displaced person \\
\cline { 2 - 3 } & Removal of trees & $\begin{array}{l}\text { Minimized tree cutting as much as possible and } \\
\text { Plantation new trees }\end{array}$ \\
\cline { 2 - 3 } & Ecological resources & Conservation of ecological resources \\
\cline { 2 - 3 } & Solid waste & $\begin{array}{l}\text { Solid waste to be segregated properly and dumped in } \\
\text { the right place. }\end{array}$ \\
\cline { 2 - 3 } & Loss of agricultural production & Cash compensation to the farmer \\
\cline { 2 - 3 } & Water quality & Construction close to water bodies should be avoided \\
\cline { 2 - 3 } & Noise \& vibration & $\begin{array}{l}\text { Adequate abatement measures for noise generation } \\
\text { carried out regularly }\end{array}$ \\
\cline { 2 - 3 } & Air pollution & $\begin{array}{l}\text { Coal transportation to be made in covered } \\
\text { truck. Unloading and coal grinding are to be carried out } \\
\text { in a closed shed }\end{array}$ \\
\hline \multirow{2}{*}{$\begin{array}{l}\text { On-site environment } \\
\text { management }\end{array}$} & Coal transportation \& grinding \\
\hline
\end{tabular}




\begin{tabular}{|l|l|l|}
\hline \multirow{2}{*}{$\begin{array}{l}\text { Occupational } \\
\text { health \& safety }\end{array}$} & $\begin{array}{l}\text { Clay transportation \& } \\
\text { storing }\end{array}$ & $\begin{array}{l}\text { Clay transportation to be done in covered trucks and } \\
\text { storing to be done in under the shade }\end{array}$ \\
\cline { 2 - 3 } & Landscaping \& greening & Create a buffer zone and planting more trees \\
\cline { 2 - 3 } & Supply \& use of PPE & $\begin{array}{l}\text { Protective clothing, goggles, helmets, shoes, and } \\
\text { accessories to be adequately provided to the workers. }\end{array}$ \\
\cline { 2 - 3 } & Dust inhalation hazard & $\begin{array}{l}\text { Provision of drinking water, separate toilets for male } \\
\text { and female workers }\end{array}$ \\
\cline { 2 - 3 } & Accident risks in the workplace & $\begin{array}{l}\text { Strict enforcement on the use of PPEôs including } \\
\text { awareness raising }\end{array}$ \\
\hline $\begin{array}{l}\text { Maintenance } \\
\text { of equipment }\end{array}$ & $\begin{array}{l}\text { Pegular maintenance and repair of drill and use of protective gears \& clothing } \\
\text { kiln, dryer \& equipment }\end{array}$ & $\begin{array}{l}\text { Implementation of a schedule for regular } \\
\text { maintenance and repair of kiln, dryer \& equipment }\end{array}$ \\
\hline $\begin{array}{l}\text { Socio-economy and } \\
\text { aesthetics }\end{array}$ & Employment & Provision of employment opportunity to local people \\
\hline
\end{tabular}

\section{Public opinion}

Most of the respondents (65\%) were agreed to continuing Brick Field Project. In spite of some losses, people were agreed to continuing the Brick Field project. This may be because of their economic and employment facilities were very poor thatôs why they need Brick Field. About 25\% were not agreed to continuing the Brick Field project. This may be because they were living far from the Brick Field or they lose their home and agricultural lands. Rest $10 \%$ of people has nothing to say about to the project.

\section{Discussion}

Research found both positive and negative effects of the brickfield project on different environmental and socioeconomic components. The project will cause agricultural land loss, productivity loss, vegetation cover damage, agricultural topsoil loss, water quality change, air pollution, ecosystem service decrease, wildlife loss, emit particulate matter, sound pollution, aquatic habitat loss, grazing land loss, cutting and burning of trees, land use change, etc. on the surrounding area of the project implementation. According to Jerin et al. (2016); World Bank (2011) brick field has a negative impact on soil fertility, agricultural production, aquaculture, vegetation, forest, quality of water, etc. The more agricultural field is being converted into brickfield this can create pressure on food security (Reazuddin, 2016). This study found that worker and surrounding people basically children and older persons will be adversely affected by burn diseases, skin problem, respiratory problem and lung problem after the brickfield constructed. The previous study on brickfield also found different health problem of worker and surrounding people by emitted dust smoke and particulate matter (Abbey et al., 1995; Jerin et al., 2016; DoE, 2007; Joshi and Dudabi, 2008; World Bank, 2011).
Construction of brickfield in this area will have a positive effect on the economic condition, social status, peopleôs lifestyle, etc. by creating more employment opportunity, small business opportunity and by industrialization (Jerin et al., 2016).

Our estimated Environmental Impact Value (EIV) is Ót2ô(Positive Two) and Leopold matrix value is 2.28, 1.56 and 1.82 in the pre, during and post construction of the project consequently. All these values show that the project has overall positive impacts on different environmental and socioeconomic components. But most of the impact assessment study on brickfield found that brickfield has overall negative impacts on different environmental components (Jerin et al., 2016; Guttikunda, 2009; Pokhrel and Lee 2014 and Tuladhar et al., 2002). Because all these studies were conducted on outdated Fixed-Chimney Kiln (FCK) brickfield, the FCK is the less efficient and most environmental polluting technologies (Pokhrel and Lee, 2014; Hossain and Abdullah, 2012; World Bank, 2011; DoE, 2007 and Reazuddin, 2016). But our study is conducted at an automatic brick manufacturing industry which will use modern Tunnel Kiln (Tk) technologies (ICPL). Tunnel Kiln is the most efficient and less polluting technology thatôs why it has an overall positive impact (Tuladhar et al., 2002; Hossain and Abdullah, 2012; World Bank, 2011; DoE, 2007 and Reazuddin, 2016).

\section{Conclusions}

After properly evaluation of environmental impact, the Environmental Impact Value was found as ñ+2ò that means this project has a positive impact on different environmental components. Evaluation of Leopold matrix shows that the pre, during and post construction 
value as $2.28,1.56$ and 1.82 . These values indicate the projectô pre-construction stage impact is moderate, during and post- construction stage impact is low on different environmental components. Though this brick kiln has some negative impacts on the environment, socio-economic condition and livelihood pattern of peoples in this area will be dramatically changed due to this brick kiln. This brick kiln will create more employment opportunity for local people. As more people getting the opportunity to work there and there will also create small to large business opportunity based on this projects so the economy of this area will be developed and peopleôs lifestyle will be standard. The major negative Impacts of this project are a loss of trees, impact on air quality, impact on surface water quality, loss of agricultural lands, loss of vegetation, loss of agricultural topsoil, impact on ecological resources, the health impact of workers and local people, noise generation from construction activities, etc. The magnitude of these negative impacts can be easily reduced by taking proper and planned mitigation measures. By evaluating different environmental impacts it can be said the negative impact due to this project is not so high. So the project can be implemented.

\section{References}

Abbey, D. E.; Lebowitz, M. D.; Mills, P. K.; Petersen, F. F.; Beeson, W. L. and Burchette, R. J. 1995. Long Term Ambient Concentrations of Particulates and Oxidants and Development of Chronic Disease in a Cohort of Non-Smoking California Residents. Inhalation Toxicology 1995 (7): $19 \ddot{1} 34$.

Ahmed, S. and Hossain, I. 2008. Applicability of Air Pollution Modelling in a Cluster of Brickfields in Bangladesh. Department of Chemical Engineering, Bangladesh University of Engineering and Technology.

BBS (Bangladesh Bureau of Statistics). 2015. Statistics and Informatics Division, Ministry of Planning, Bangladesh.

BUET (Bangladesh University of Engineering and Technology). 2007. Small study on air quality of impacts of the North Dhaka brickfield cluster by modeling of emissions and suggestions for mitigation measures including financing models. Chemical Engineering Department, BUET.

Chindaprasirt, P. \& Pimraksa, K. 2008. A study of fly ashïlime granule unfired brick. Powder Technology, 182(1): 33-41.
Guttikunda, S. 2009. Impact analysis of brick kilns on the air quality in Dhaka, Bangladesh. SIM-Air Working Paper Series, p. 234

DoE (Department of Environment). 2007. National Strategy for Sustainable Brick Production in Bangladesh. Ministry of Environment and Forest, Government of the Peopleôs Republic of Bangladesh.

Hossain, M. and Abdullah, A. M. 2012. Securing the Environment: Potentiality of Green Brick in Bangladesh, BUP Journal, 1(1): 79-89

ICPL (Innovation Consulting Private Limited). 2016. Market Study on The Brick Field Industry of Greater Barisal Region of Bangladesh, Dhaka, IDCOL Bangladesh, p.4.

IUSS (International Union Soil Science). 2002. Soil and the environment, IUSS Commission VIII. World Cong of Soil Science, International Union Soil Science, Thailand, p. 66

Jerin, M. F.; Mondol, S. K.; Sarker, B. C.; Rimi, R. H. and Aktar, S. 2016. Impacts of Brick Fields on Environment and Social Economy at Bagatipara, Natore, Bangladesh. Journal of Environmental Science \& Natural Resources, 9(2): 30-34.

Joshi, S. K. and Dudani, I. 2008. Environmental Health Effects of Brick Kilns in Kathmandu Valley, Kathmandu University Medical Journal, 6(21): 11

Krishnamoorthy, B. 2005. Environmental Management. Prentice Hall of India, New Delhi 110001. pp. 62-74.

Kundu, B. R. 2011. Feasibility study of Lebukhali Bridge on Barisal - Patuakhali road (n8).

Ostro, B. 1994. Estimating the Health Effects of Air Pollution: A Method with an Application in Jakarta. Policy Research Working Paper 1301, World Bank, Washington, DC

Pope, C. A.; Burnett, R. T.; Thun, M. J.; Calle, E. E.; Krewski, D.; Ito, K. and Thurston, G. 2002. Lung Cancer, Cardiopulmonary Mortality, and Long-Term Exposure to Fine Particulate Air Pollution. Journal of the American Medical Association, 287 (9): $1132 \mathrm{i} 41$.

Pokhrel, R. and Lee, H. 2014. Integrated Environment Impact Assessment of Brick Kiln using Environmental Performance Scores. Asian Journal of Atmospheric Environment, 8(1): 15-24.

Rahim. 2011. Real Estate Business in Bangladesh: Opportunities and Challenges, 1(5):2.

Reazuddin, M. 2016. Post Implementation Environmental Monitoring Report, Tradexcel Auto Bricks Limited, Angutia, Mirzapur, 
Gazipur. BAN: Financing Brick Kiln Efficiency Improvement Project.

Saha, S. K. 2007. Environmental Impact Assessment. AH Development publishing house, New Market, Dhaka. p.165

Tuladhar, B. and Raut, A.K. 2002. Environmental and health impact of Kathmanduôs brick kilns. Clean Energy Nepal (CEN).

UNDP (United Nation Development Programme). 2011. Eco-friendly brick technique helps build a cleaner Bangladesh. [Available online at]:

https://www.undp.org/content/undp/en/home/ presscenter/articles/2011/06/20/eco-friendlybrick-technique-helps-build-a-cleanerbangladesh.html. [Assessed; $5^{\text {th }}$ April 2019].

Wilson, L. 1998. A Practical Method for Environmental Impact Assessment Audits. Environ Impact Assess Rev, 18: 59-71

World Bank. 2011. Introducing Energy-efficient Clean Technologies in the Brick Sector of Bangladesh. Report No. 60155-BD. Environment, Climate Change, and Water Resources Unit South Asia Region, World Bank. 